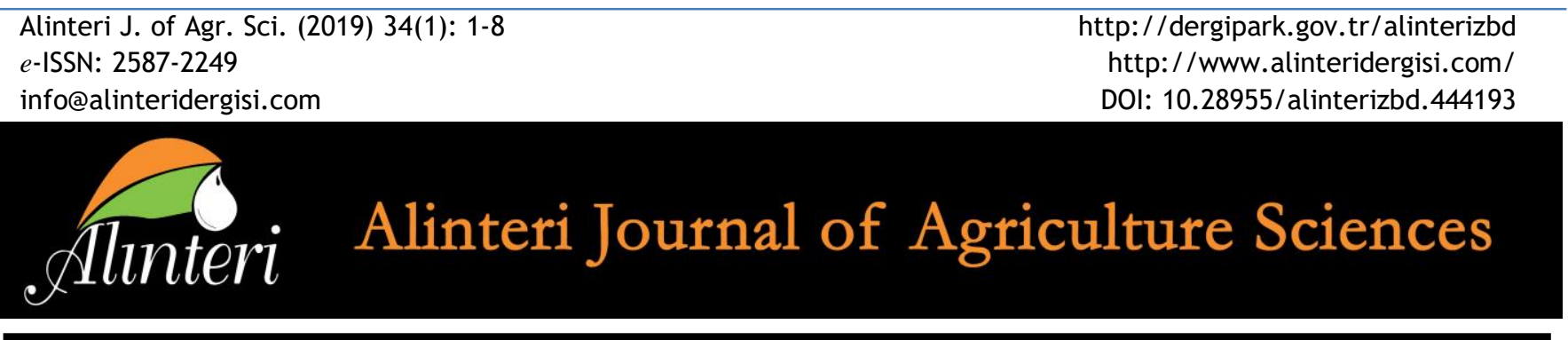

RESEARCH ARTICLE

\title{
Soil Erosion Risk Assessment due to Land Use/Land Cover Changes (LULCC) in Bulgaria From 1990 to 2015
}

\author{
Emre Özșahin*, İlker Eroğlu
}

Namık Kemal University, Faculty of Art and Science, Department of Geography, Tekirdağ/Turkey

\author{
Keywords: \\ Bulgaria \\ Soil erosion \\ LULCC \\ RUSLE (3D) \\ GIS
}

ARTICLE INFO

Article History:

Received: 16.07 .2018

Accepted: 11.09.2018

Available Online: 20.03.2019

\begin{abstract}
A B S T R A C T
Soil erosion by water jeopardizes land use/cover changes (LULCC) for anthropogenic reasons. It results in enormous and irreversible damage if no action is taken. The Balkan Peninsula has experienced considerable LULCC in recent years; however, the influence of such changes on soil erosion has not been adequately explored. This study sought to explore the influence of LULCC in Bulgaria on soil erosion. Annual soil loss quantity was estimated, and the erosion risk classes were defined using the RUSLE (3D) method based on Geographical Information Systems (GIS). The results of this study indicated that annual soil loss in Bulgaria has been decreasing recently due to various support practices (P-factor) rather than LULCC. However, the recent increase in severe erosion risk class indicates that measures against soil erosion are critical for land degradation.
\end{abstract}

Please cite this paper as follows:

Özșahin, E. and Eroğlu, İ. (2019). Soil Erosion Risk Assessment due to Land Use/Land Cover Changes (LULCC) in Bulgaria From 1990

to 2015. Alinteri Journal of Agriculture Sciences, 34(1): 1-8. doi: 10.28955/alinterizbd.444193

\section{Introduction}

Land use/land cover changes (LULCC) have become more complicated and multidimensional (Latocha et al 2016) in recent years. This situation has given rise to special LULCC contrary to nature, resulting in a large number of changes in the global climate system and the biosphere (Riebsame et al., 1994). These changes primarily include soil erosion by water, which is considered the most important geoenvironmental hazard (Kavian et al., 2017). This phenomenon responds very rapidly to LULCC and has caused serious damage throughout the World (Conforti and Buttafuoco, 2017).

Soil erosion is a widespread problem, particularly in various parts of the Balkan Peninsula (Rousseva, 2012; Milevski and Ivanova, 2013; Blinkov, 2015; Özșahin et al., 2018). However, the effect of LULCC on soil erosion in this region is not well known (Hengl et al., 2007). Bulgaria is one of the critical countries in the Balkan Peninsula suffering major LULCC (Rousseva, 2002a; 2002b; Rousseva and Stefanova, 2006; Rousseva et al., 2003; 2006a; 2006b; 2010; 2016). Indeed, the Bulgarian land has been threatened by uncontrolled LULCC over the last few decades (Rousseva and Stefanova, 2006; Rousseva et al., 2006a; Kercheva and Krasteva, 2007). Since the early 1990s, many agricultural land in the country has been abandoned due to soil erosion (Shishkov and Kolev, 2014).

This study aims to determine the effect of LULCC in Bulgaria on soil erosion. The study used the Revised Universal Soil Loss Equation-3D (RUSLE-3D) model based on Geographic Information Systems (GIS). This model has been widely used in similar studies (Ganasri and Ramesh, 2016; Conforti and Buttafuoco, 2017) and provides quantitative data addressing the effect of LULCC on soil erosion in more concrete terms.

\footnotetext{
* Corresponding author

E-mail address: eozsahin@nku.edu.tr
} 
Thus, it can be used to help determine the way and extent to which LULCC affect soil erosion.

\section{Materials and Methods}

\section{Study Area}

The study area covers Bulgaria, which is one of the strategic countries in the Balkan Peninsula (Figure 1). It is located at latitude $40^{\circ} 01^{\prime} 29^{\prime \prime}$ - $42^{\circ} 07^{\prime} 04^{\prime \prime}$ north of the Equator and longitude $26^{\circ} 02^{\prime} 02^{\prime \prime}-29^{\circ} 08^{\prime} 23^{\prime \prime}$ east of Greenwich.

The geology of the study area is composed of rocks of different ages and species dating from the Precambrian era. The main stages of the development of this land took place over approximately 3.5 billion years and include the PreNeogene, Neogene, and Quaternary eras (Shishkov and Kolev, 2014).

The average altitude is $470 \mathrm{~m}$, and much of the land consists of mountains and hills. Approximately $66 \%$ of the land has a slope of more than 3 degrees. The land dominated by a high and sloping topography is composed of several large physiological units that run in parallel lines and have deep geological features (Anonymous, 1982).

The climate of the study area is temperate continental with a transition towards a subtropical climate in its Mediterranean version (in the southern parts of the country). According to the meteorological data, the mean annual temperature is $12.13^{\circ} \mathrm{C}$ and the mean annual precipitation is $648 \mathrm{~mm}$ (Anonymous,
2016).

Various soil types occur in the Bulgarian land due to the effects of relief, parent rocks, bio-climatic conditions, and other factors. The most widely spread soil groups include Luvisol, Chernozems, Cambisol, Pseudopodsolic soils, Fluvisols, and Vertisols. The rough terrain and high slope values of the study area generally cause erosion hazards depending on other suitable natural conditions (Shishkov and Kolev, 2014). Indeed, soil erosion is the greatest threat to soil resources in Bulgaria (Rousseva and Stefanova, 2006) due to natural environmental conditions as well as land use and management that accelerate soil erosion processes (Rousseva, 2012). In addition, land use in Bulgaria has been affected by water erosion at a rate of $65 \%$ and wind erosion at a rate of 24\% (Rousseva et al., 2006a; Rousseva et al., 2010).

Accelerated soil erosion by anthropogenic activity in Bulgaria dates back to the 1950s and has caused severe damage to the national economy over time, becoming a crucial issue on the national agenda in the early 1970s (Blinkov et al., 2013). Since the early 1990s, considerable activities have been carried out to control soil erosion that threatened agricultural areas (Rousseva et al., 2006b; Shishkov and Kolev, 2014). Hence, studies on soil erosion, which have been conducted regularly since 1956, have been conducted more systematically in the last few decades (Rousseva et al., 2006a). To this end, important steps have been taken to decrease soil erosion. For example, studies to estimate soil erosion have been conducted based on erosion models supported by GIS techniques (Rousseva et al., 2010).

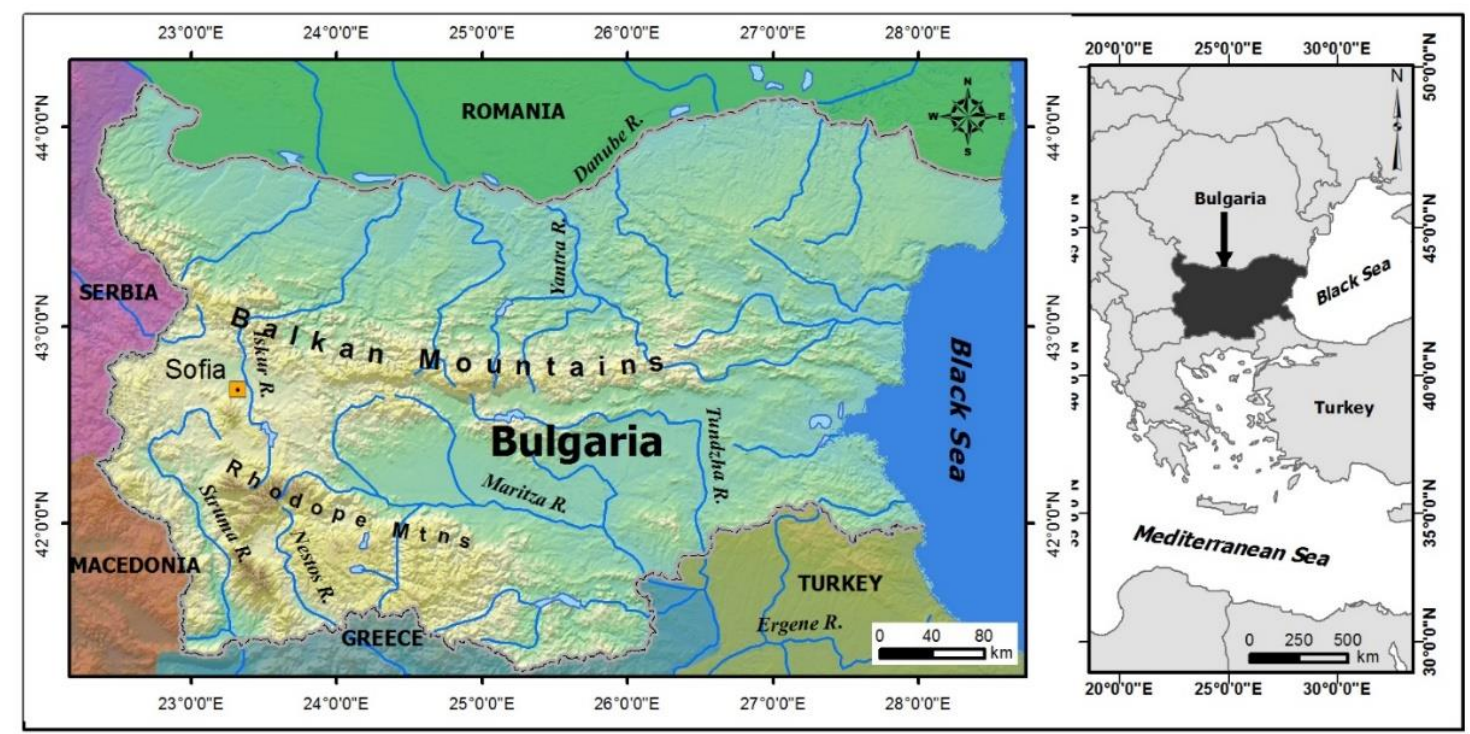

\section{Method}

Figure 1. Location map of the study area

This study uses the RUSLE model based on GIS technologies. It applies the RUSLE-3D equation (1) proposed by Renard et al. (1997).

$$
A=R \times K \times L S \times C \times P
$$

where (Equation 1) $\mathrm{A}=$ annual mean soil loss ( $\mathrm{t} \mathrm{ha} \mathrm{a}^{-1}$ per year), $\mathrm{R}=$ rainfall erosivity factor $\left(\mathrm{MJ} \mathrm{ha}^{-1}\right.$ per year $), \mathrm{K}=$ soil erodibility factor ( $\mathrm{t}$ ha $\mathrm{h} \mathrm{MJ}^{-1} \mathrm{~mm}^{-1}$ ), $\mathrm{C}=$ cover-management factor (dimensionless), LS = slope length and slope steepness factor (dimensionless), and $\mathrm{P}=$ support practices factor (dimensionless).

The input factors of the research method were obtained from various sources. The R-factor (Rousseva and Stefanova, 2006; Panagos et al., 2015a; Ballabio et al., 2017), K-factor (Rousseva and Stefanova, 2006; Panagos et al., 2014), and Pfactor (Panagos et al., 2015b) were retrieved from the studies involving high resolution $(100 \mathrm{~m})$. The LS-factor (Panagos et al., 2015c) was calculated through a comparison of the recent 
Digital Elevation Model (DEM) obtained by the Shuttle Radar Topography Mission (SRTM) and the data from the present research. The $\mathrm{C}$-factor was based on the data sets retrieved from the CORINE Land Cover (CLC) system for the 1990 and 2012 LULCC. Meanwhile, land use land cover change (LULCC) data for 2012 were updated in accordance with the data reported by Panagos et al. (2015d) to obtain the C-factor data for 2015. All these factors were mapped on a 1:100.000 scale in line with all the data used in the study.

The RUSLE-3D model that forms the basis of the study involves fixed and controllable variables to predict soil erosion. The fixed variables include soil erodibility (K-factor) and slope length and slope steepness (LS-factor), and the controllable variables include rainfall erosivity (R-factor), cover-management (C-factor), and support practices ( $\mathrm{P}$ factor) (Renard et al., 1997).

This study applied the RUSLE-3D equation by combining the cover-management factor (C-factor) maps generated in different years (1990-2015) based on the LULCC provided that all other factors (R-, K-, LS-, and P-factors) remain constant (Figure 2). Thus, it sought to analyze the effect of LULCC on soil erosion in different years.

Following the application of the model, two different erosion maps with a resolution of $100 \times 100$ m were generated for 1990 and 2015. These maps were categorized using erosion risk classes (low, slight, medium, severe, and very severe), which have commonly been used in similar studies (Özșahin and Uygur, 2014; Panagos et al., 2015e). Afterwards, the areas falling under these classes as well as their distribution were interpreted from a geographical perspective. In addition, total annual soil loss quantities for the relevant years were obtained, and the data were compared. The reasons underlying the changes over time were analyzed and reviewed to consider their possible future influences.

\section{Results and Discussion}

\section{LULCC}

The phenomenon of erosion is considered to be the main soil degradation process in Bulgaria. It was even accepted as a national issue with primary importance due to its serious harms to national economy in the early 1970s. Since 1990, attempts have been made to reduce it by taking various measures [e.g., studies on rational land management, development of soil protection policies, and formation of permanent crop pattern]. Accordingly, understanding the current status of the phenomenon of erosion in Bulgaria requires the investigation of the change in the impact of this phenomenon in the period from 1990 to 2015 (Rousseva et al., 2006b).

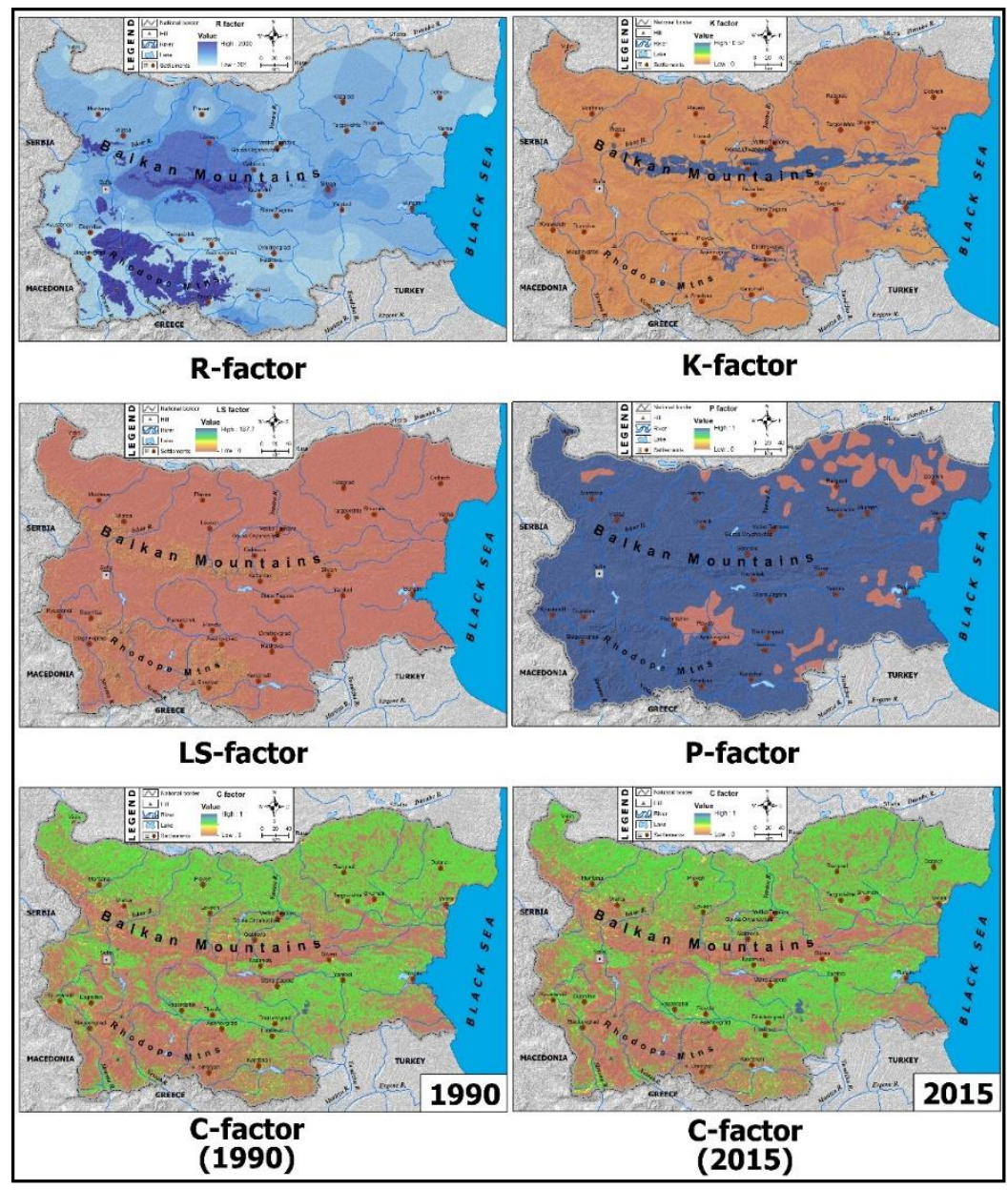

Figure 1. Factor maps of the RUSLE-3D method. 
The $\mathrm{C}$-factor reflects the effects of plant cover, crop breeding, and management practices on erosion and is basically determined by today's rapid LULCC stemming from anthropogenic causes (Riebsame et al., 1994). Such uncontrolled changes that intensify soil erosion are lessened by various efforts, including the conservation and rehabilitation of natural vegetation and afforestation. However, such efforts are still quite inadequate in many countries of the world (Walling, 2009). Thus, it is more important today to make efforts that focus on meaningful changes in the C-factor depending on LULCC in order to determine the ultimate temporal and areal effects of erosion. Such efforts primarily involve observing the effect of LULCC on erosion. The $\mathrm{C}$-factor-one of the main parameters predicting soil erosion-has shown a difference as a result of the small but statistically significant LULCC in the study area over the last 25 years (1990-2015) (see Figure 2; Table 1). Table 1 shows the major changes leading to these differences.

Table 1. Rate (\%) of areal distribution of LULC class in Bulgaria

\begin{tabular}{llll}
\hline LULC classes & \multicolumn{3}{c}{ Area (\%) } \\
\cline { 2 - 4 } (1st level) & $\mathbf{1 9 9 0}$ & $\mathbf{2 0 1 5}$ & Change \\
\hline Artificial surfaces & 4.863 & 4.765 & -0.098 \\
Agricultural areas & 51.505 & 51.571 & 0.066 \\
Forests and semi natural areas & 42.691 & 42.663 & -0.028 \\
Weetlands & 0.101 & 0.100 & -0.001 \\
Water bodies & 0.841 & 0.901 & 0.060 \\
\hline
\end{tabular}

The main change in the LULCC classes occurred in the artificial surfaces. In the study area, although the artificial surfaces occupied $4.86 \%$ in 1990 , the rate declined to $4.76 \%$ in 2015 (Table 1). This spatial shrinkage acceleration appearing on artificial surfaces may have derived from the developments on mineral extraction sites rather than the changes taking place in settlement or infrastructure areas. As a matter of fact, mineral extraction sites are the main driver of artificial development in Bulgaria, which is one of the countries where urban sprawl is the slowest in Europe (Anonymous, 2018). Accordingly, extension of mineral extraction sites is the main factor causing changes on artificial surfaces. The result is an expansion in the agricultural areas and water bodies, compared to an areal contraction in the forests, semi-natural areas, and wetlands (Table 1). The expansion of the agricultural areas stems from the transformation of forests, semi-natural areas, and wetlands into agricultural land. The areal expansion of the water bodies results from the dams built on rivers. Similar changes have been reported in various parts of the Balkan Peninsula (Jelecek et al., 2007; Panagos et al., 2015b).

LULCC in the study area suggest that the C-factor is the most important controllable variable affecting soil erosion. Thus, uncontrolled LULCC in the study area are most likely to pose a threat of degradation, especially to the agricultural land, in the near future. Rousseva (2006) argued that, since the 1990s, the area covering the abandoned lands has been increasing to a considerable extent due to the decrease in the agriculturally convenient lands, which contributes to the severity of erosion. Shishkov and Kolev (2014) reported a considerable decrease in annual soil loss due to agriculturally convenient lands being replaced by abandoned lands. Özșahin (2016) also reported a threat of degradation to the agricultural land due to the uncontrolled LULCC in the Ergene River basin in the southern part of the study area in the Thracian Peninsula. In this sense, if the actual LULCC continues, it will be possible to foresee a negative change in soil erosion in the near future.

\section{Soil Erosion by Water}

The C-factor composing the RUSLE-3D model showed a difference between 1990 and 2015. The areal and proportional distribution of erosion risk for these years was calculated based on the analysis of other factors that affect soil erosion by water (Table 1; Figure 3).

Table 2. Areal and proportional distribution of erosion risk classes

\begin{tabular}{llllll}
\hline \multirow{2}{*}{ Erosion Risk Class } & \multirow{2}{*}{ Soil Loss Class $\left(\mathrm{t} \mathrm{ha}{ }^{-1}\right.$ per year) } & \multicolumn{2}{c}{1990} & \multicolumn{2}{c}{2015} \\
\cline { 3 - 6 } & & Area $\left(\mathrm{km}^{2}\right)$ & Rate $(\%)$ & Area $\left(\mathrm{km}^{2}\right)$ & Rate $(\%)$ \\
\hline Low & $<-0.5$ & 87802 & 78.67 & 87805 & 78.68 \\
Slight & $0.5-1$ & 5840 & 5.23 & 5870 & 5.26 \\
Moderate & $1.01-2$ & 5447 & 4.88 & 5462 & 4.89 \\
High & $2.01-5$ & 5678 & 5.09 & 5687 & 5.10 \\
Severe & $5.01->$ & 6834 & 6.12 & 6777 & 6.07 \\
& & 111602 & 100 & 11602 & 100 \\
\hline
\end{tabular}

Accordingly, the erosion risk in Bulgaria differed during the time period studied and has recently tended to decline ($0.051 \%)$. However, this downward trend in severe erosion risk has been compensated by the upward trends of almost equal rates $(+0.050 \%)$ seen in other erosion risk classes (Table 2$)$. The statistical analysis of the variation of the erosion risk classes proved the significance of the results (Table 3 ). In the study area, all these changes observed in the erosion risk classes seem to have resulted from anthropogenic LULCC. In fact, Rousseva et al. (2006a) explained that current land management in Bulgaria increases erosion risk rather than natural conditions. 

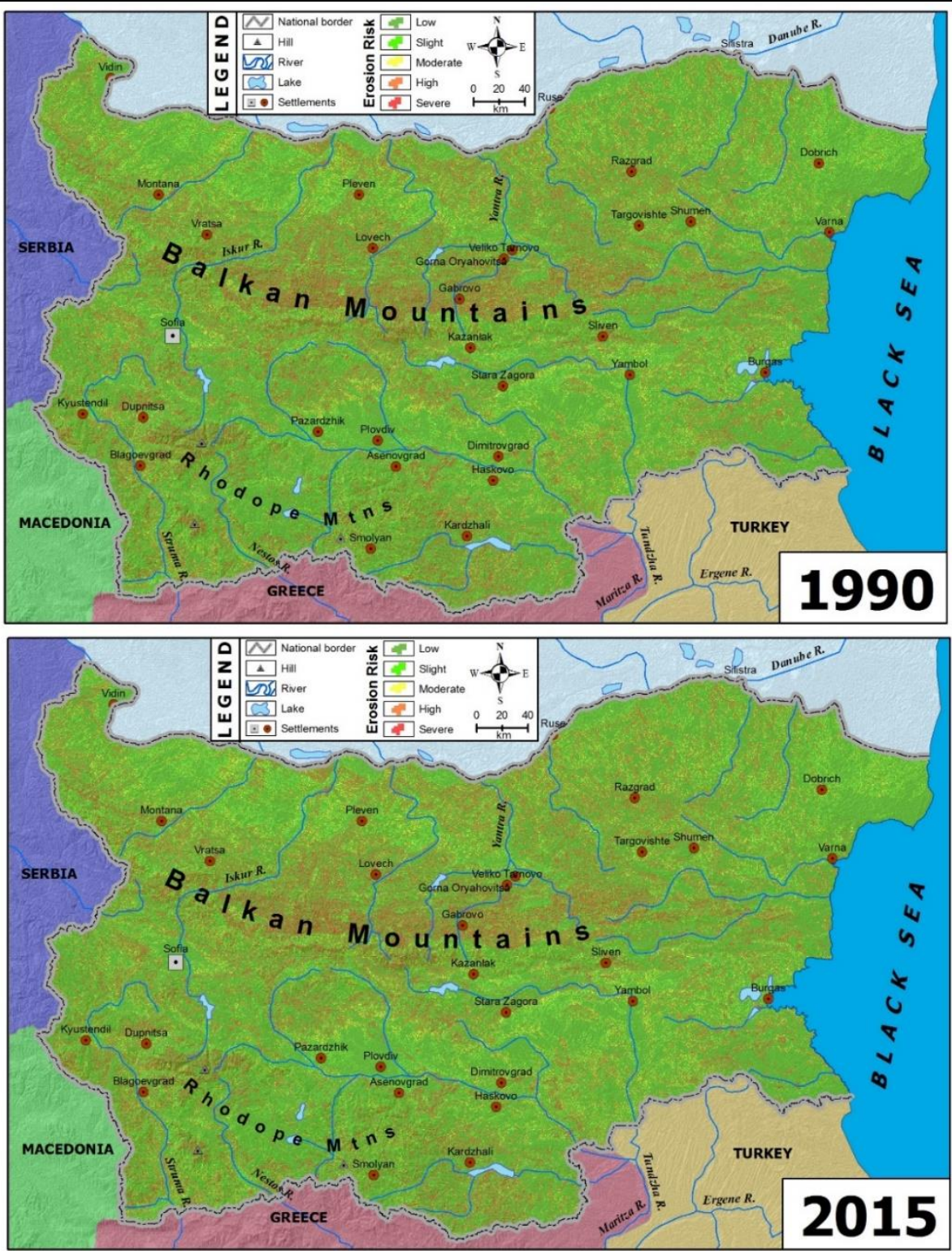

Figure 3. The classified erosion risk distriution map for 1990 and 2015

Table 3. Comparative zonal statistical analysis results of erosion risk classes in the study area

\begin{tabular}{lllllllll}
\hline Erosion Risk Class & $\mathrm{t}$ & $\mathrm{df}$ & Sig. (2-tailed) & Mean Difference & Range & Sum & Mean & Std. Deviation \\
\hline Low & 15735.000 & 1 & 0.000 & 78.67500 & 0.01 & 157.35 & 78.6750 & 0.00707 \\
Slight & 349.667 & 1 & 0.002 & 5.24500 & 0.03 & 10.49 & 5.2450 & 0.02121 \\
Moderate & 977.000 & 1 & 0.001 & 4.88500 & 0.01 & 9.77 & 4.8850 & 0.00707 \\
High & 1019.000 & 1 & 0.001 & 5.09500 & 0.01 & 10.19 & 5.0950 & 0.00707 \\
Severe & 243.800 & 1 & 0.003 & 6.09500 & 0.05 & 12.19 & 6.0950 & 0.03536 \\
\hline
\end{tabular}

The areal distribution of the erosion risk classes in Bulgaria also varied between years, and the soil loss mostly occurred on the slopes of mountainous terrain with high slope values. Very severe erosion has been observed particularly along the slopes of Balkan Mountains and Rhodope Mountains (Figure 3). The LSfactor, which reflects the effect of both the LULCC including the $\mathrm{C}$-factor and the topography, was prominent as the determining factor in the increase of soil loss due to its high sensitivity to erosion.

The mean soil loss due to spatiotemporal variations of erosion risk in Bulgaria is also an important indicator of the dimension of soil erosion. Accordingly, the highest soil loss was observed in 1990 with $2.20 \mathrm{t} \mathrm{ha}^{-1}$ per year. Afterwards, this rate showed a considerable decrease and, in 2015, was just $2.13 \mathrm{t} \mathrm{ha}^{-1}$ per year. In particular, the status of the mean soil loss in the area corresponds to the results from similar studies conducted within Europe (Panagos et al., 2015e) and the Balkan Peninsula (Blinkov, 2015).

The relationship between LULCC classes and the mean annual rate of soil loss $\left(\mathrm{tha}^{-1} \mathrm{y}^{-1}\right)$ was also explored as it 
would reveal the effect of LULCC in Bulgarian territory on erosion. The LULCC with the biggest decrease in the mean annual soil loss was found to be cultivated areas (Table 4; Figure 4). As a matter of fact, the mean annual soil loss, which was 3.42 in 1990, fell to 3.40 in 2015 in these areas. This fall in soil loss in cultivated areas may be a product of the policies developed for the protection of cultivated areas after 1990. Indeed, Rousseva et al. (2006b) argue that since 1990, the regulations made in Bulgaria as a result of the radical changes in the political system have been an important factor influential on decreased soil loss in cultivated areas. Over the same period, similar rates of change took place in artificial surfaces and forests and semi natural areas in positive and negative directions, respectively. Moreover, the mean average soil loss declined in water bodies, but did not change in wetlands (Table 4; Figure 4).

Table 4. Change in mean annual soil loss according to LULCC classes

\begin{tabular}{llll}
\hline \multirow{2}{*}{ LUC classes (1st level) } & \multicolumn{3}{c}{ Soil Loss Class (t ha ${ }^{-1}$ per year) } \\
\cline { 2 - 4 } & $\mathbf{1 9 9 0}$ & $\mathbf{2 0 1 5}$ & Change \\
\hline Artificial surfaces & 0.83 & 0.84 & +0.01 \\
Agricultural areas & 3.42 & 3.30 & -0.12 \\
Forests and semi natural & 1.12 & 1.11 & -0.01 \\
areas & 0.0001 & 0.0001 & +0.0000 \\
Weetlands & 0.003 & 0.001 & -0.002 \\
Water bodies & & &
\end{tabular}

\section{Conclusion}

The present study has found that the erosion risk and mean soil loss in Bulgaria differed between years. The severity of soil erosion and mean soil loss have recently tended to decline as a result of these changes. However, the downward trend seen only in the severe erosion risk was neutralized by the upward trend of almost equal rates $(+0.050 \%)$ in other erosion risk classes. All these variations and areal differentiations in soil erosion in Bulgaria have been affected primarily by the LULCC shaped under the control of anthropogenic activities, thereby determining the C-factor in the RUSLE-3D model. Garcia-Ruiz et al. (2013) suggest that similar conditions reflecting soil erosion trends have basically stemmed from human activities. The results of the present study concur with those of the research reanalyzing the soil erosion and soil loss in Europe using a similar method. Panagos et al. (2015b; 2015d) highlight that the main cause of the recent decrease in the mean annual soil loss in the European continent is the support practices ( $\mathrm{P}$ factor) that consequently improve the C-factor. In addition, the changes taking place in Bulgaria due to socio-economic reasons (e.g., not being used in land capability classification based on ecological features, impacts of incorrect stubble tillage practices, failed crop rotation, deforestation, conversion from cultivated land into forestlands, heavy grazing, insufficient soil and water conservation measures) are also in line with other regions of the Balkan Peninsula (Milevski and Ivanova, 2013; Blinkov, 2015; Özșahin, 2016).

This study revealed that anthropogenic activities are the most important direct or indirect indicators of erosion phenomena. Furthermore, the main contributor to soil erosion is LULCC under human control. Nevertheless, anthropogenic measures that enhance the effect of support practices (Pfactor), thereby improving the $\mathrm{C}$-factor, can reduce the influence of the erosion phenomenon. Finally, this paper demonstrated that the GIS-based RUSLE-3D method is very suitable for showing erosion risk and soil loss in terms of spatiotemporal variations.

\section{Acknowledgements}

The authors would like to thank Prof. Dr. Svetla Rousseva for her essential role in the process of data collection. We would also thank the referees for their valuable comments which helped to improve the manuscript.

\section{References}

Anonymous (1982) Geography of Bulgaria, Natural conditions and resources. Bulgarian Academy of Sciences, Sofia (514 pp) (In Bulgarian).

Anonymous (2016b) Compensating the of Land degradation in Turkey. National Report. Republic of Turkey Ministry of Forestry and Water Management, Ankara (in Turkish).

Anonymous (2018) Statistical Reference Book 2018. In A. Ilkova (Eds), National Statistical Institute, Sofia (271 pp).

Ballabio C, Borrelli P, Spinoni J, Meusburger K, Michaelides S, Beguería S, Klik A, Petan S, Janeček M, Olsen P, Aalto $J$, Lakatos $M$, Rymszewicz A, Dumitrescu A, Perčec Tadić M, Diodato N, Kostalova J, Rousseva S, Banasik K, Alewell C, Panagos P (2017) Mapping monthly rainfall erosivity in Europe. Science of The Total Environment 579: $1298-1315$.

Blinkov I (2015) The Balkans - The Most Erosive Part Of Europe?. Bulletin of the Faculty of Forestry 110: 9-20.

Blinkov I, Kostadinov S, Marinov I (2013) Comparison of erosion and erosion control works in Macedonia, Serbia and Bulgaria. International Soil and Water Conservation Research 1: 15-28.

Conforti M, Buttafuoco G (2017) Assessing space-time variations of denudation processes and related soil loss from 1955 to 2016 in southern Italy (Calabria region). Environmental Earth Sciences 76: 457-475.

Ganasri B P, Ramesh H (2016) Assessment of soil erosion by RUSLE model using remote sensing and GIS - A case study of Nethravathi Basin. Geoscience Frontiers 7: 953 . 961.

Guzmán G, Quinton J N, Nearing M A, Mabit L, Gómez J A (2013) Sediment tracers in water erosion studies: current approaches and challenges. J Soils Sediments 13: 816-833.

Hengl T, Panagos P, Jones A, Toht G (Edited By) (2007) Status and prospect of soil information in south-eastern Europe: soil databases, projects and applications, Institute for Environment and Sustainability. JRC Scientific and Technical Reports, Italy.

Jelecek L, Chromy P, Janac J (2007) Origins of Landscape Differences and Related Causes of Causes of Change in Land use (LU): East Central and Southeast Europe from 
1960s Until the Post-Communist Present. In J Kabrda \& I Bičík (Eds), Man in the landscape across frontiers: Landscape and land use change in Central European border regions (pp. 81-89), CD-ROM Conference Proceedings of the IGU/LUCC Central Europe Conference 2007, Faculty of Science, Charles University in Prague, Czech Republic.

Kavian A, Sabet S H, Solaimani K, Jafari B (2017) Simulating the effects of land use changes on soil erosion using RUSLE model. Geocarto International 32 (1): 97-111.

Kercheva M, Krasteva V (2007) IV. Overview of soil information and soil protection policies in Bulgaria. In: T Hengl, $\mathrm{P}$ Panagos, A Jones \& $G$ Tóth (Eds), Status and prospect of soil information in southeastern Europe: soil databases, projects and applications (pp. 33-42), JRC Scientific and Technical Reports, European Communities, Italy.

Latocha A, Szymanowski M, Jeziorska, J, Stec M, Roszczewska $M$ (2006) Effects of land abandonment and climate change on soil erosion-An example from depopulated agricultural lands in the Sudetes Mts, SW Poland. Catena 145: 128-141.

Milevski I, Ivanova E (2013) Erosion potential modeling of the territory of municipalities pehchevo and simitli using remote sensing data. Ninth Scientific Conference with International Participation SPACE, ECOLOGY, SAFETY 20-22 November 2013, Sofia, Bulgaria.

Özşahin E (2016) The Effects Of LULCC (Land use and Land cover Changes) in Ergene Basin (Thrace) On Erosion. Anadolu J Agr Sci. 31: 117-126 (in Turkish).

Özșahin E, Uygur V (2014) The effects of land use and land cover changes (LULCC) in Kuseyr plateau of Turkey on erosion. Turkish Journal of Agriculture and Forestry 38: 478-487 (in Turkish).

Özșahin E, Duru Ü, Eroğlu I (2018) Land Use and Land Cover Changes (LULCC), a Key to Understand Soil Erosion Intensities in the Maritsa Basin. Water 10, 335; doi: $10.3390 /$ w10030335.

Panagos P, Meusburger K, Van Liedekerke M, Alewell C, Hiederer R, Montanarella L (2014) Assessing soil erosion in Europe based on data collected through a European Network. Soil Science and Plant Nutrition 60 (1): 15-29.

Panagos P, Ballabio C, Borrelli P, Meusburger K, Klik A, Rousseva S, Tadic M P, Michaelides S, Hrabalíková M, Olsen P, Aalto J, Lakatos M, Rymszewicz, A, Dumitrescu A, Beguería S, Alewell C (2015a) Rainfall erosivity in Europe. Sci Total Environ 511: 801-814.

Panagos P, Borrelli P, Meusburger K, Van der Zanden, E H, Poesen J, Alewell C (2015b) Modelling the effect of support practices (P-factor) on the reduction of soil erosion by water at European Scale. Environmental Science \& Policy 51: 23-34.

Panagos P, Borrelli P, Meusburger K (2015c) A new European slope length and steepness factor (LS-Factor) for modeling soil erosion by water. Geosciences 5: 117-126.

Panagos P, Borrelli P, Meusburger C, Alewell C, Lugato E,
Montanarella L (2015d) Estimating the soil erosion cover-management factor at European scale. Land Use Policy 48C: 38-50.

Panagos P, Borrelli P, Poesen J, Ballabio C, Lugato E, Meusburger K, Montanarella L, Alewell C (2015e) The new assessment of soil loss by water erosion in Europe. Environmental Science \& Policy 51: 438-447.

Renard K G, Foster G R, Weessies G A, McCool D K (1997) Predicting soil erosion by water: a guide to conservation planning with the revised universal soil loss equation (RUSLE). In Agriculture Handbook 703, Ed. Yoder DC. U.S. Department of Agriculture, Washington, DC.

Riebsame W E, Meyer W B, Turner B L (1994) Modeling landuse and cover as part of global environmental change. Climate Change 28 (1-2): 45-64.

Rousseva S (2002a) Information bases for developing a geographic database for soil erosion risk assessments. Monograph. N. Poushkarov Institute of Soil Science, Sofia, p. 198.

Rousseva S (2002b) Databank on the field plots for soil erosion studies in Bulgaria. In: Rubio J L, Morgan RPC, Asins S, Andreu V (Eds.), Man and Soil at the Third Millennium, Volume: 2, GEOFORMA Ediciones, S.L. Logrono, Spain, pp. 1635-1646.

Rousseva S (2006) Stocktaking of land degradation in agriculture. Discussion report. Project 00043507 Capacity Building for Sustainable Land Management in Bulgaria.http://www.unccd.slm.org/files/LD_Agri_EN G_Svetla\%20Rousseva.pdf. Accessed 23-26 May 2006.

Rousseva S (2012) Factors and rates of soil erosion in the Balkan Peninsula. In Christov, I. (Ed), Proceedings of International Conference "Ecology Interdisciplinary Science and Practice (Part One, 43-47), Sofia.

Rousseva S, Stefanova V (2006) Assessment and mapping of soil erodibility and rainfall erosivity in Bulgaria. In: M. Morel et al. (eds) BALWOIS 2006 Conference on Water Observation and Information System for Decision Support, 23-26 May 2006, Ohrid, Republic of Macedonia. Book of Abstracts (ISBN 9989-9594-1-2): 28-29. http: //balwois.com/wpcontent/uploads/old_proc/ffp-607.pdf.

Rousseva S, Lazarov A, Tsvetkova E, Bakalov I, Djodjov H, Dimitrov P, Krumov V, Nekova D, Malinov I, Lozanova L, Vateva V (2003) Monitoring, information system and measures for erosion control of the agricultural lands. Final report of Project No 3 funded by the National Centre for Agrarian Sciences.

Rousseva S, Lazarov A, Stefanova V, Malinov I (2006a) Soil Erosion Risk assessments in Bulgaria. In: Morel $M$ et al. (eds) BALWOIS 2006 conference on water observation and information system for decision support, Ohrid, Republic of Macedonia. Book of abstracts (ISBN 99899594-1-2), pp 29-30. http://balwois.com/wpcontent/uploads/old_proc/ffp-608.pdf. Accessed 23-26 May 2006.

Rousseva S, Lazarov A, Tsvetkova E, Marinov I, Malinov I, Krumov V, Stefanova V (2006b). Soil erosion in Bulgaria. 


\section{In: J Boardman \& J Poesen (Eds), Soil Erosion in Europe} (pp. 167-181), London: John Wiley Ltd.

Rousseva S, Lozanova L, Nekova D, Stefanova V, Ch Djodjov Tsvetkova E, Malinov I, Kroumov V, ChehlarovaSimeonova S (2010) Soil Erosion Risk in Bulgaria and Recommendations for Soil Protective Use of Agricultural Land. Part I: Northern Bulgaria (304 pp) \& Part II Southern Bulgaria (320 pp).

Rousseva S, Malinov I, Stefanova V (2016) Soil Erosion Risk Assessments Using GIS Technologies - Bulgarian Experience. Bulgarian Journal of Agricultural Science 22 (2): 205-208.

Shishkov T, Kolev N (2014) The Soils of Bulgaria. World Soils Book Series, Series (Editor Prof. Alfred E. Hartemink, Department of Soil Science, FD Hole Soils Laboratory University of Wisconsin-Madison, USA). 